\title{
Right-sided endocarditis in the non-drug addict
}

\author{
D.P. Naidoo
}

Department of Medicine, PO Box 17039 University of Natal, Medical School, Congella, Republic of South Africa

\begin{abstract}
Summary: Fifteen patients with right-sided infective endocarditis during a 5 year period (1985-1990) were retrospectively reviewed. Isolated tricuspid valve involvement occurred in nine patients.

Staphylococcus aureus was the causative organism in seven cases; four were culture negative. The diagnosis was established by two-dimensional echocardiography in 11 patients and at postmortem in the remaining four patients who succumbed shortly after admission. Fever, tachypnoea and pneumonia were universal features. A successful outcome ensued in eight patients with medical therapy alone and in two patients who were submitted to valve replacement. Five patients died, two from uncontrolled infection with repeated pulmonary emboli.

Right-sided infective endocarditis should be suspected in any pneumonic illness that complicates post-abortal infection or other inadequately treated sepsis. Two-dimensional echocardiography is important in diagnosis since cardiac signs are minimal at presentation.
\end{abstract}

\section{Introduction}

Infection localized to the right heart valves occurs in about $5 \%$ of cases of infective endocarditis. ${ }^{1}$ In the western world this disease is seen mainly in drug addicts and as a complication of indwelling catheters in the subclavian vein. ${ }^{2}$ Despite the high prevalence of rheumatic heart disease in our environment and the practice of traditional healing methods by unsterile skin scarification, infection of the right side of the heart is an unusual occurrence. Furthermore diagnosis is rendered more difficult when signs of left heart disease overshadow those of the right side. Consequently there have been only scant reports of right-sided infective endocarditis (RSIE) from Third World countries. ${ }^{3-4}$ This paper details our recent experience with the use of two-dimensional echocardiography is establishing a diagnosis of RSIE in a population in which rheumatic heart disease is endemic and intravenous drug abuse uncommon.

\section{Material and methods}

The case records of 20 patients diagnosed as RSIE in the 5 year period 1986-1990 were analysed. The diagnosis was established by clinical criteria, positive blood cultures, and/or demonstration of vegetations on the tricuspid or pulmonary valve.

Correspondence: $\quad$ D.P. Naidoo, M.R.C.P.(UK), F.C.P.(SA), D.C.H.(SA).

Accepted: 23 March 1993
Patients in whom no causative organisms were isolated were only included as cases of right-sided endocarditis if confirmatory evidence was obtained at surgery or postmortem. Thus four patients with suggestive clinical features but who did not have positive blood cultures or vegetations demonstrated at echocardiography were excluded from analysis. A 3 year old child who developed infection upon a congenital ventricular septal defect was also excluded from analysis. The remaining 15 adult patients admitted over the 5 year period to medical wards form the subject of this report. Autopsies were performed in four patients, in one the diagnosis had been made antemortem and in another the diagnosis of infective endocarditis was made on clinical assessment, but the right side was not considered to be involved by the infective process and was only revealed at autopsy.

\section{Results}

Except for a 55 year old man, the patients were young adults (mean age 27 years). In six of seven females vegetations were confined to the tricuspid valve (cases 1-6); in the remaining nine patients the infection was located on the pulmonary valve (2), the tricuspid valve (5), the tricuspid and mitral (1), and the tricuspid, mitral and aortic valves (1). Conditions which predisposed to infective endocarditis are listed in Table I. The source of the infection was the genital tract in five of the seven females; in three of these it occurred post-abortion. 
Table I Presenting manifestations in RSIE

\begin{tabular}{|c|c|c|c|c|c|c|c|c|}
\hline $\begin{array}{l}\text { Case } \\
\text { no. }\end{array}$ & $\begin{array}{l}\text { Agel } \\
\text { sex }\end{array}$ & $\begin{array}{l}\text { Source/portal } \\
\text { of entry }\end{array}$ & Precordium & $\begin{array}{l}\text { Peripheral } \\
\text { signs }\end{array}$ & $\begin{array}{l}\text { Chest } \\
\text { radiograph }\end{array}$ & Organism & Outcome & $\begin{array}{l}\text { Site of } \\
\text { vegetation } \\
\text { (echo) }\end{array}$ \\
\hline 1 & $25 \mathrm{~F}$ & I/C abortion & $\begin{array}{l}\text { ESM-later } \\
\text { PSM/RVF }\end{array}$ & $\begin{array}{l}\text { Fever, } \\
\text { tachypnoea }\end{array}$ & $\begin{array}{l}\text { RML and LLL } \\
\text { consolidation }\end{array}$ & S. aureus & $\begin{array}{l}\text { Died. } \\
\text { PM: TVE }\end{array}$ & $\mathrm{T}$ \\
\hline 2 & $30 \mathrm{~F}$ & $\begin{array}{l}\text { Oral sepsis } \\
\text { (epileptic) }\end{array}$ & ESM & $\begin{array}{l}\text { Fever, } \\
\text { tachypnoea }\end{array}$ & $\begin{array}{l}\text { Thin-walled } \\
\text { cavities }+ \\
\mathbf{R} \text { effusion }\end{array}$ & $\begin{array}{l}\text { Fuso- } \\
\text { bacterium } \\
\text { nucleatum }\end{array}$ & Improved & $\mathrm{T}$ \\
\hline 3 & $32 \mathrm{~F}$ & Not known & $\begin{array}{l}\text { PSM } \\
\text { pulmonary } \\
\text { hypertension }\end{array}$ & $\begin{array}{l}\text { Clubbing, } \\
\text { pulsatile } \\
\text { hepatomegaly }\end{array}$ & $\begin{array}{l}\text { RUL and LLL } \\
\text { consolidation }\end{array}$ & Nil & $\begin{array}{l}\text { Improved: } \\
\text { pulmonary } \\
\text { hypertension }\end{array}$ & $\mathrm{T}$ \\
\hline 4 & $20 \mathrm{~F}$ & $\begin{array}{l}\text { Genito- } \\
\text { urinary } \\
\text { sepsis }\end{array}$ & $\begin{array}{l}\text { ESM } \\
\text { later } \\
\text { PSM/RVF }\end{array}$ & $\begin{array}{l}\text { Fever, } \\
\text { tachypnoea }\end{array}$ & $\begin{array}{l}\text { Basal } \\
\text { opacities + } \\
\text { effusions }\end{array}$ & S. aureus & Died & $\mathbf{T}$ \\
\hline 5 & $25 \mathrm{~F}$ & I/C abortion & Nil & $\begin{array}{l}\text { Fever, } \\
\text { tachypnoea } \\
\text { triangular } \\
\text { opacities }\end{array}$ & $\begin{array}{l}\text { RLL } \\
\text { consolidation + }\end{array}$ & S. aureus & $\begin{array}{l}\text { Improved } \\
\text { TVR }\end{array}$ & $\mathbf{T}$ \\
\hline 6 & $30 \mathrm{~F}$ & I/C abortion & $\begin{array}{l}\text { ESM } \\
\text { later } \\
\text { PSM/RVF }\end{array}$ & $\begin{array}{l}\text { Fever, } \\
\text { tachypnoea }\end{array}$ & $\begin{array}{l}\text { Diffuse } \\
\text { rounded } \\
\text { opacities }\end{array}$ & S. aureus & Improved & $\mathbf{T}$ \\
\hline 7 & $19 \mathrm{~F}$ & $\begin{array}{l}\text { Placental } \\
\text { abruption }\end{array}$ & ESM & $\begin{array}{l}\text { Fever, } \\
\text { tachypnoea }\end{array}$ & $\begin{array}{l}\text { Diffuse } \\
\text { infiltrates } \\
\mathbf{R} \text { effusion }\end{array}$ & Nil & $\begin{array}{l}\text { Died. } \\
\text { PM: PVE }\end{array}$ & Not done \\
\hline 8 & $20 \mathrm{M}$ & $\begin{array}{l}\text { Unknown: } \\
\text { underlying } \\
\text { rheumatic } \\
\text { heart disease }\end{array}$ & PSM & $\begin{array}{l}\text { Fever, } \\
\text { splinters, } \\
\text { roth spots }\end{array}$ & $\begin{array}{l}\text { Left ventri- } \\
\text { cular failure } \\
\text { (R) basal effusion }\end{array}$ & S. aureus & $\begin{array}{l}\text { Died } \\
\text { PM: aortic, } \\
\text { mitral + } \\
\text { TVE }\end{array}$ & Not don \\
\hline 9 & $24 \mathrm{M}$ & $\begin{array}{l}\text { 'Stab heart' } \\
\text { VSD }\end{array}$ & $\begin{array}{l}\text { Nil-later } \\
\text { PSM/RVF }\end{array}$ & $\begin{array}{l}\text { Fever, } \\
\text { splinters, } \\
\text { roth spots, } \\
\text { clubbing }\end{array}$ & $\begin{array}{l}\text { LLL } \\
\text { consolidation }\end{array}$ & S. aureus & Improved & $\mathrm{T}+\mathrm{VSP}$ \\
\hline 10 & $29 \mathrm{M}$ & Urethritis & $\begin{array}{l}\text { EDM (pul- } \\
\text { monary) }\end{array}$ & $\begin{array}{l}\text { Fever, } \\
\text { tachypnoea }\end{array}$ & $\begin{array}{l}\text { (R) basal } \\
\text { opacity }\end{array}$ & Nil & Improved & $\mathbf{P}$ \\
\hline 11 & $11 \mathrm{M}$ & $\begin{array}{l}\text { Abscess on } \\
\text { thigh }\end{array}$ & $\begin{array}{l}\text { ESM later } \\
\text { PSM/RVF }\end{array}$ & $\begin{array}{l}\text { Fever, } \\
\text { night sweats }\end{array}$ & $\begin{array}{l}\text { (R) basal } \\
\text { pneumatocoele }\end{array}$ & S. aureus & $\begin{array}{l}\text { Improved } \\
\text { TVR }\end{array}$ & $\mathbf{T}$ \\
\hline 12 & $15 \mathrm{M}$ & $\begin{array}{l}\text { Septic } \\
\text { polyarthritis }\end{array}$ & RVF & $\begin{array}{l}\text { Fever, } \\
\text { tachypnoea, } \\
\text { arthralgia }\end{array}$ & $\begin{array}{l}\text { Pneumatocoeles, } \\
\text { bibasal } \\
\text { effusions }\end{array}$ & Nil & $\begin{array}{l}\text { Improved } \\
\text { pericardiotomy }\end{array}$ & ny \\
\hline 13 & $32 \mathrm{M}$ & $\begin{array}{l}\text { 'Stab heart' } \\
\text { VSD }\end{array}$ & Nil & $\begin{array}{l}\text { Fever, } \\
\text { clubbing, } \\
\text { digital } \\
\text { infarcts }\end{array}$ & $\begin{array}{l}\text { Diffuse } \\
\text { rounded } \\
\text { opacities }+ \\
\text { effusions }\end{array}$ & Diphtheroids & Improved & $V$ \\
\hline 14 & $38 \mathrm{M}$ & $\begin{array}{l}\text { Peritonitis, } \\
\text { enterocolic } \\
\text { fistula }\end{array}$ & Nil & $\begin{array}{l}\text { Fever, } \\
\text { tachypnoea, } \\
\text { collapse }\end{array}$ & $\begin{array}{l}\text { Thin-walled } \\
\text { cavities with } \\
\text { bilateral } \\
\text { consolidation }\end{array}$ & Nil & $\begin{array}{l}\text { Died } \\
\text { PM: TVE }\end{array}$ & Not don \\
\hline 15 & $55 \mathrm{M}$ & $\begin{array}{l}\text { Not known: } \\
\text { underlying } \\
\text { valve prolapse }\end{array}$ & $\begin{array}{l}\text { PSM } \\
\text { biventricular } \\
\text { failure }\end{array}$ & $\begin{array}{l}\text { Fever, } \\
\text { clubbing, } \\
\text { pulsatile } \\
\text { hepatomegaly }\end{array}$ & $\begin{array}{l}\text { Left ventricular } \\
\text { failure and } \\
\text { basal effusions }\end{array}$ & $\begin{array}{l}\text { S. epider- } \\
\text { midis }\end{array}$ & $\begin{array}{l}\text { Improved } \\
\text { DVR }\end{array}$ & $\mathbf{T}+\mathbf{M}$ \\
\hline
\end{tabular}

I/C abortion = incomplete abortion; $\mathrm{ESM}^{=}$systolic ejection murmur; $\mathrm{PSM} / \mathrm{RVF}=$ pan-systolic murmur of tricuspid regurgitation (PSM) with right ventricular failure (RVF); TVR = tricuspid valve replacement; DVR = double (mitral 0 and tricuspid) valve replacement; TVE = tricuspid valve endocarditis; $T=$ tricuspid valve; $P=$ pulmonary valve; $\omega$ $M=$ mitral valve; $V S D=$ ventricular septal defect; $R M L=$ right middle lobe; $L L L=$ left middle lobe; $P M=$ post- -0 mortem; RUL = right upper lobe; VE = valve endocarditis; EDM = early diastolic murmur. 
An inadequately treated abscess on the thigh, septic polyarthritis, enterocolic fistula and a penetrating injury of the heart (stab heart) were identified as the source of infection in five of the eight males. Although the source could not be identified in the male patient with pulmonary valve endocarditis, gonococcal infection was suspected because of a history of recent urethral discharge and pus cells on urinalysis. Underlying heart disease was present in the remaining two patients: mitral and tricuspid valve prolapse (1) and rheumatic mitral and aortic regurgitation (1). Pulmonary parenchymal involvement was the dominating feature in all patients and manifested predominantly as lower zone consolidation with cavitation and pleural effusion. The embolic aetiology of the lesions were confirmed on ventilation-perfusion scans in six patients. Two patients died from uncontrolled sepsis and macroembolism, and a third from concomitant left-sided involvement with heart failure. Two patients came to autopsy undiagnosed: one had peritonitis and an enterocolic fistula from a penetrating duodenal ulcer, and the other had a placental abruption with signs of septicaemia. One patient ('stab heart') absconded from hospital while recovering on treatment and has not returned for a follow-up visit.

Peripheral embolic phenomena (roth spots, splinter haemorrhages) were noted in three patients, all with concomitant left-sided disease. Similarly clubbing and splenomegaly was noted in three patients, two of whom had left-sided disease. The white cell count was significantly elevated $\left(>12 \times 10^{9} / 1\right)$ in 11 of the 15 patients and was associated with marked anaemia and elevated sedimentation rate.

The clinical and pathological feature of these patients are summarized in Table I. Salient features are described in the illustrative case report that follows.

\section{Case report: no. 11}

An 11 year old male was admitted in December 1988 with a one month history of loss of appetite, loss of weight and night sweats. Three weeks previously he had an incision and drainage of an abscess in the thigh. On examination he was pale, pyrexial and tachypnoeic. Crackles were audible at the right base. Precordial examination was normal. The thigh incision showed healthy granulation tissue. The chest radiograph confirmed right lower lobe consolidation and parenteral penicillin was prescribed. No clinical or radiological evidence of osteitis was present. On the fourth day cloxacillin and amikacin were added to his treatment when blood culture yielded Staphylococcus aureus. The patient appeared to improve but at the end of the first week complained of pleuritic left-sided chest pain. Signs of consolidation were present on the left side of the chest with a swinging temperature and the development of rigors. Vancomycin $(400 \mathrm{mg}$ 8 hourly) was added to his treatment and he was transfused. Repeat chest radiography showed leftsided consolidation and a pneumatocoele had appeared at the right base (Figure 1). After slight improvement, he again became pyrexial with further signs of consolidation at the left base. Again $S$. aureus, sensitive to cloxacillin, was isolated from blood culture. At this time a short systolic ejection murmur was heard at the left sternal edge and thought to be a flow murmur due to anaemia.

Antibiotic therapy was continued but the pyrexia did not abate and he was referred for a cardiac assessment 10 days later when a gallop rhythm became audible. Careful examination again revealed no peripheral stigmata of infective endocarditis. At the left sternal edge a short diastolic murmur in addition to the systolic murmur could be heard. Echocardiography revealed a large vegetation that prolapsed freely between the right atrium and the right ventricle (Figure 2). $\mathrm{He}$ was referred for surgery but this had to be delayed for 2 weeks because of the development of chicken pox. During this period he remained tachypnoeic and pyrexial and had repeated bouts of pleuritic chest pain. Signs of right ventricular failure developed and the systolic murmur became more pronounced.

At surgery the septal leaflet of the tricuspid valve was completely destroyed and a $2 \mathrm{~cm}$ vegetation was found in this region. The leaflet was excised and tricuspid annuloplasty performed. Postoperatively control of the infection was easily obtained. Residual tricuspid regurgitation remained upon discharge.

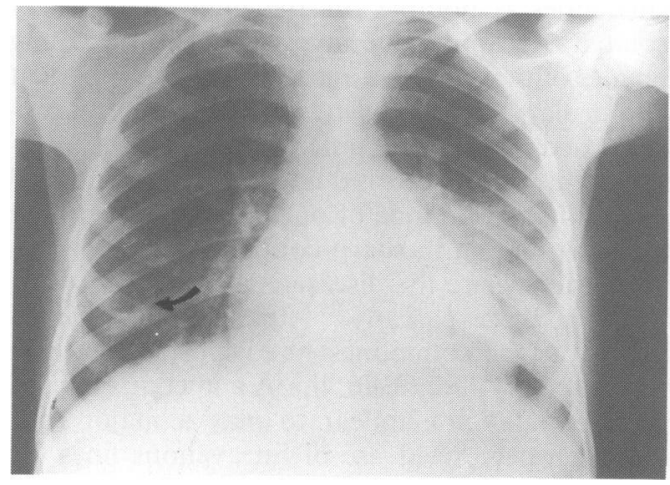

Figure 1 Repeat chest radiograph showing new consolidation on the left and the development of a pneumatocoele at the right base (arrow). 


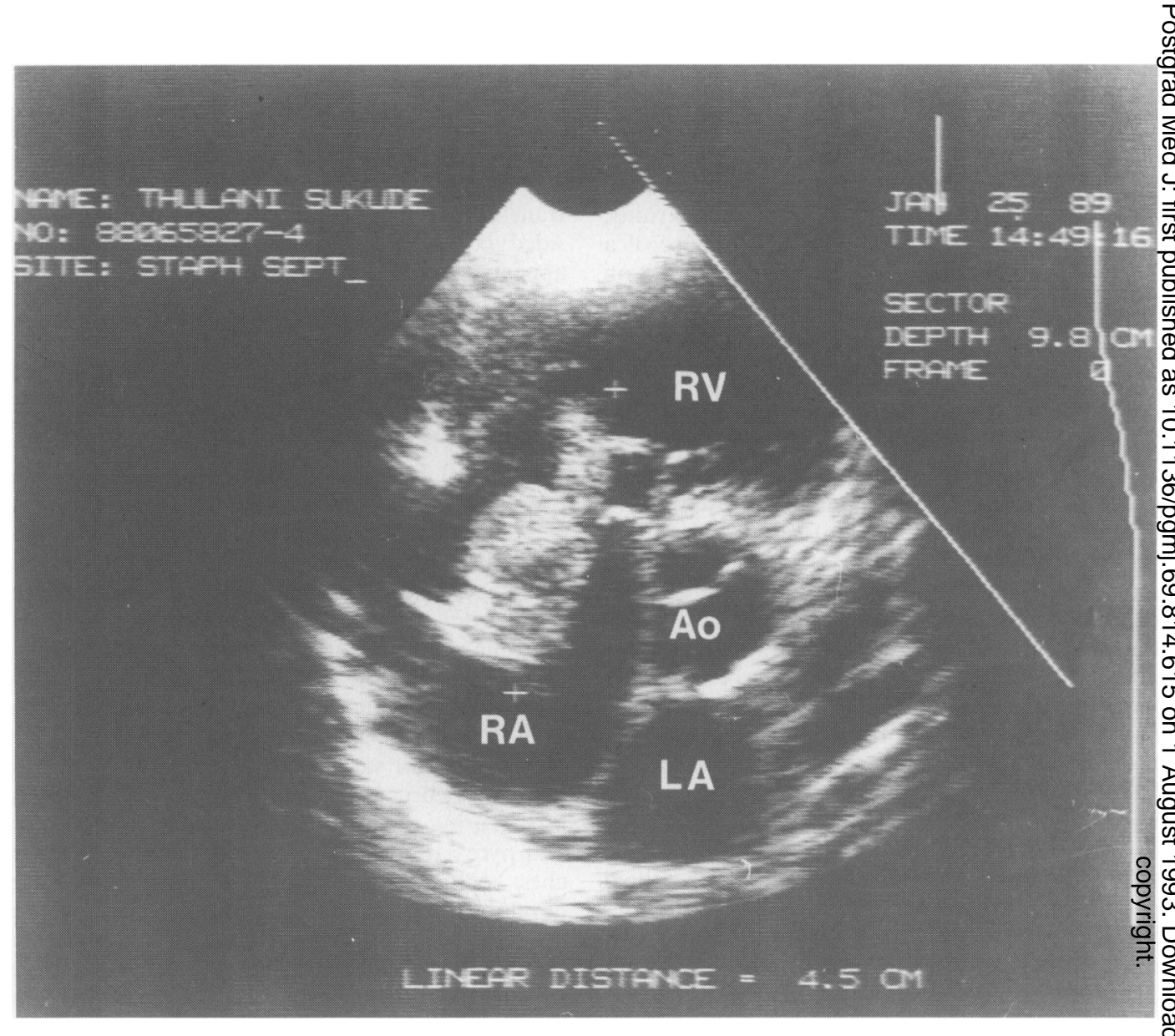

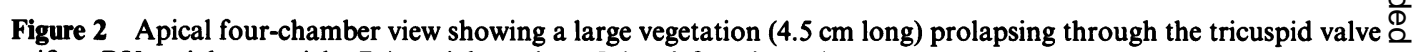
orifice. $\mathbf{R V}=$ right ventricle; $\mathbf{R A}=$ right atrium; $\mathbf{L A}=$ left atrium; $A o=$ aorta.

\section{Discussion}

This series is notable for the high incidence of isolated tricuspid valve involvement in six young females of reproductive age. Except for the patient with prolapsing leaflet syndrome and the autopsydiagnosed case of rheumatic valvular disease, infection in this series occurred upon previously normal tricuspid valves. None of our patients was a drug addict, a finding in sharp contrast to the western experience where the disease is almost exclusively found in these patients. ${ }^{1,6,7}$ Inadequately treated sepsis was the commonest predisposing factor in our patients. Alcoholism, burns and compromised immunity did not appear to play a major role. Although prolonged use of intravenous lines for parenteral alimentation, drug infusion and haemodynamic monitoring cause suppurative thrombosis and afford access to the cardiac valves, we did not identify a definite case of RSIE from this route. Staphylococcus aureus was the commonest organism isolated; in four patients no organism 3 . was grown on blood culture. Culture negativity of $\dot{\sigma}$ systemic venous blood is known to occur in RSIE ${ }^{1,8}$ and in these patients echocardiography응 had diagnostic value. ${ }^{9}$

As exemplified in other series clinical recognition음 of RSIE was often delayed because pulmonary $>$ manifestations rather than signs of right heart failure were the usual presenting symptoms. ${ }^{10,11}$ Fever, chest pain, cough and haemoptysis due to septic pulmonary emboli were the commonest $\tilde{\circ}$ symptoms. Persistent pyrexia with reappearing ${ }_{\omega}^{N}$ infiltrates suggested septic embolic episodes and prompted referral for echocardiography to searcho for vegetations on the right heart valves. Pul- $\frac{\nwarrow}{\Phi}$ monary infiltrates on the chest radiograph were $\stackrel{?}{?}$ usually multiple with a tendency to recur in different parts of the lung, affecting mainly the lower lobes. ${ }^{7} S$. aureus was the causative organism 
in six of ten patients who had cavitation; the diagnosis was mistaken for tuberculosis in three patients because of cavitating lesions with effusion.

Although systolic murmurs were documented at some time during their hospital stay in all but two of our patients, it was misdiagnosed as a flow murmur (systolic ejection type at the left sternal edge) due to anaemia in five cases. A typical murmur of tricuspid regurgitation (soft, holosystolic murmur that increased on inspiration) was audible on admission in only three patients. In four patients no murmur could be heard on admission. ${ }^{10,11}$ When the murmur of tricuspid regurgitation did develop subsequently signs of heart failure were already in an advanced stage as a result of valve disruption from uncontrolled infection. ${ }^{12}$

The diagnosis was established in 11 patients by two-dimensional echocardiography. This procedure has repeatedly been shown to have diagnostic value in RSIE even when precordial signs are minimal; ${ }^{12-15}$ it permits the visualization of vegetations and identification of complications such as flail chordae and ring abscess. The size of vegetations on the echocardiogram may have prognostic implications. It is said that because vegetations attain a large size in RSIE there is poor antibiotic penetration and this may lead to difficulty in eradicating a more resistant organism. ${ }^{16}$ Thus patients with large vegetations may require surgery because of more serious infection and resultant pulmonary parenchymal damage. ${ }^{17,18}$ This has been our experience in the two patients with isolated tricuspid valve endocarditis who demised and in the two who had surgery.

All three patients operated upon in this series had active infection as indicated by positive blood culture, constitutional symptoms and new embolic phenomena in the preceding 48 hours. The primary

\section{References}

1. Roberts, W.C. \& Buchbinder, N.A. Right-sided valvulus endocarditis: a clinopathological study of twelve necropsy patients. Am J Med 1972, 53: 7-19.

2. Cross, S.A. \& Stiegbigel, R.T. Infective endocarditis and access site infections in patients on haemodialysis. Medicine 1976, 55: 453-466.

3. Josi, V.R. \& Sainani, G.S. Staphylococcal tricuspid valve endocarditis. J Assoc Phys India 1986, 34: 833-834.

4. Van der Westhuizen, R.A.G. Right-sided valvular infective endocarditis. S Afr Med J 1987, 71: 25-27.

5. Swift, P.J. Staphylococcus aureus tricuspid valve endocarditis in young women after gynaecological events. $S$ Afr Med J 1984, 66: 891-893.

6. Banks, T., Fletcher, R. \& Ali, N. Infective endocarditis in heroin addicts. $\mathrm{Am} J \mathrm{Med}$ 1973, 55: 444-451.

7. Reisberg, B.E. Infective endocarditis in the narcotic adult. Prog Cardiovasc Dis 1979, 22: 193-204.

8. Hubbell, G., Cheitlin, M.D. \& Rapaport, E. Presentation management and follow-up evaluation of infestive endocarditis in drug addicts. Am Heart $J$ 1981, 102: 85-94. indications for surgery in most series remains persisent sepsis and macroembolism, the aim being to debride and drain all infected valvular and paravalvular tissues. It has been pointed out that patients with persistent fever and recurrent pulmonary emboli do not usually require surgery as they respond well to antibiotics and that toxicity from spiking fever, pleuritic chest pain, cough, haemoptysis and dyspnoea may continue for weeks despite appropriate antibiotic therapy. ${ }^{19}$ We consider infection refractory if approximately ten days of appropriate antibiotic therapy fails to effect substantial improvement in clinical state and other known causes of pyrexia have been sought and treated. ${ }^{20}$

Death in our patients was due to clinically unrecognized infection (2), concomitant left-sided involvement (1) and uncontrolled infection with septic macroemboli and right heart decompensation (2). Postponement of surgery in the hope of seeking an antibiotic cure led to recurrent septic pulmonary emboli, respiratory failure and death in the last two patients (Cases 1 and 4).

In Third World countries, inadequately treated sepsis and post-abortal infection are significant predisposing factors for the development of RSIE. $S$. aureus remains the commonest causative organism. Even in the absence of murmurs, echocardiography has diagnostic value in patients with anaemia, persistent fever and reappearing lung infiltrates. Surgery should be considered at an earlier stage in the management of infection refractory to medical therapy.

\section{Acknowledgement}

We wish to thank Mrs Previna Ramhorry who kindly typed the manuscript.
9. O'Brien, J.T. \& Gieser, E.A. Infective endocarditis and echocardiography. Am Heart J 1984, 108: 386-394.

10. Robbins, M.J., Soeiro, R., Frishman, W.H. \& Strom, J.A. Right-sided valvular endocarditis: aetiology, diagnosis and an approach to therapy. Am Heart J 1986, 111: 128-135.

11. Panadis, I.P., Kotler, M.N., Mintz, E.S., Segal, B.L. \& Ross, J.R. Right heart endocarditis: clinical and echocardiographic features. Am Heart J 1984, 107: 759-764.

12. Ginzton, L.E., Siegel, R.J. \& Criley, J.M. Natural history of tricuspid valve endocarditis: a two dimensional echocardiographic study. Am J Cardiol 1982, 49: 1853-1859.

13. Kisslo, J., von Ramm, O.T., Harvey, R., Jones, R., Juk, S.S. \& Behar, V.S. Echocardiographic evaluation of tricuspid valve endocarditis: an m-mode and two dimensional echocardiographic study. Am J Cardiol 1976, 38: 502-507.

14. Mintz, G.S., Kotler, M.N., Segal, B.L. \& Parry, W.R. Comparison of two-dimensional and m-mode echocardiography in the evaluation of patients with infective endocarditis. Am J Cardiol 1979, 43: 738-744. 
15. Berger, M., Delfin, L.A., Jelveh, M. \& Goldberg, E. Twodimensional echocardiographic findings in right-sided endocarditis. Circulation 1980, 61: 855-861.

16. Weinstein, L. \& Schlisinger, J. Pathoanatomic, pathophysiologic and clinical correlations in endocarditis. $N$ Engl $J$ Med 1974, 291: 832-838.

17. Bayer, A.S., Blomquist, I.K., Bello, E., Chiu, M.S., Ward, J.I. \& Ginzton, L.E. Tricuspid valve endocarditis due to Staphylococcus aureus: correlation of two-dimensional echocardiography with clinical outcome. Chest 1988, 93: 247-253.
18. Robbins, M.J., Frater, R.W.M., Soeiro, R., Frishman, W.H. \& Strom, J.A. Influence of vegetation size on clinical outcome of right-sided infective endocarditis. Am J Med 1986, 80: 165-171.

19. Dinubile, M. Surgery for addiction-related tricuspid valve $C$ endocarditis. Am J Med 1987, 82: 811-813.

20. Chan, P., Ogilby, J.D. \& Segal, B. Tricuspid valve endocar- $\overrightarrow{\overline{\bar{\omega}}}$ ditis. Am Heart J 1989, 117: 1140-1146. 